\title{
Big Hole Shaped Charge Debris Control Research and Application in BOHAI Oilfield
}

\author{
Sheng Ting-Qiang ${ }^{1}$ \\ Technology Department \\ .China Oilfield Services Limited \\ Tianjin, China \\ shengtq@cosl.com.cn
}

\author{
Xu Wen-Xin ${ }^{2}$ \\ Research and Development Center \\ Xi'an WuHua Juneng Blasting Equipment CO., LTD. \\ Xi'an, Shaanxi, China \\ skd21355@163.com
}

\author{
Li Bi-Hong ${ }^{3}$ \\ Research and Development Center \\ Xi'an WuHua Juneng Blasting Equipment CO., LTD. \\ Xi'an, Shaanxi, China \\ 6160946@qq.com \\ Li Shang-Jie ${ }^{4}$ \\ Research and Development Center \\ Xi'an WuHua Juneng Blasting Equipment CO., LTD. \\ Xi'an, Shaanxi, China \\ zbdx04081401@163.com
}

\begin{abstract}
Based on the Bohai oilfield, which geological condition is unconsolidated heavy oil reservoir, which is targeted to design a new 7 "high shot density big debris shaped charge. used several kinds of technology in this research, such as numerical simulation analysis on the formation of shaped charge case debris and jet using AOTUDY and ANSYS/LS-DYNA software, and steel target test, single charge case debris collected test and 7 "perforating gun debris collected test. The experiment results show that: Numerical simulation of debris formation and jet has good consistency with ground test results. The big debris rate of new shaped charge is better than that of common ones. The most of debris lost get away from the gun aperture, which size is less than $9.53 \mathrm{~mm}$, most debris still stay in the perforating gun. According to the application in Bohai oilfield, the new $7 "$ perforator satisfied the requirements of the heavy oil gravel pack completion and multilayer injection process. After the perforation perforator debris total quality loss are less than $0.5 \mathrm{Kg} / \mathrm{ft}$., the actual drop debris mass is far less than the drop debris of the quality of $2.22 \mathrm{Kg}$ during the test process. The big debris forming effect is good, most of which still stay in the perforating gun, to ensure the perforating operation safety and subsequent completion process smoothly.
\end{abstract}

Keywords-Big debris; shaped charge; Numerical simulation; Bohai oilfield

\section{INTRODUCTION}

Bohai oilfield is currently the largest offshore oil China, but also the country's second largest oil production base, the geological characteristics of the reservoir is unconsolidated, structural fracture, fracture development, complex reservoir, reservoir in fluvial, Delta, buried hill, heavy oil reserves accounted for more than $65 \%$. With the development of oil and gas exploitation and human's need, accordingly to improve the oil and gas production is also put forward higher requirements. How to enhance the productivity of oil is one of the difficult problems in the development process of heavy oil. The highly deviated and horizontal wells technology is widely used in offshore oil and gas field development, its economic benefit is more superior to the straight well.

In the process of perforating completion operation, the case of shaped charge breaks into sizes, irregular debris by the function of high energetic materials. These debris fall into the well under the effects of explosion products, some debris block the tunnel of perforation, which make the oil and gas channel unsmooth. Especially during the process of lifting the perforating guns, some small debris may fall into well-shaft through the gun perforation, not only pollute the wellbore environment, but also will increase the frictional resistance between the gun and the casing, which will lead to the construction accident easily. OrientXact perforation system of Schlumberger adopts low-debris shaped charge in oriented perforating technology, to achieve the purpose of debris control, reduce construction risks. Baker also uses the low-debris technique to control the case debris [1-5]. In the paper, we mainly discuss in the 7' perforator design method of big debris shaped charge, numerical simulation, performance test and application in Bohai oilfield.

\section{DESIGN CONCEPT}

The structure design of case use pre-control debris theory. Pre-control fragment is also called semiprefabricated fragment, by the special technical control or guide case to break so as to control the size, shape and number of fragments formed. Many kinds of structure are usually used in the military affairs, such as case groove type, shaped charge liner; charge surface groove, the casing area embrittlement. fragments of control theory develop over a long time in the domestic and foreign, almost on military application, such as grenades, ammunition warhead etc., especially in the application of fragment warhead. In the pre-control fragment technology, the process of grooving inner surface of case is easy, long storage performance is good, the smaller effect of case strength, low manufacturing cost, which has good effects in control fragments of case. Petroleum perforation can be widely used. 
According to the structure of shaped charge[6], case groove type is mainly adopted. The case groove is divided into the inner surface of groove, outer surface groove, inner and outer surface groove. There are many kinds of common geometry of groove, such as diamond shaped, rectangular, V-shaped, sawtooth. In order to obtain long flake fragments, the inner surface of case carved V-shaped groove structure. Fig .1 is a simplified model of the case V-shaped groove [7], which can be used for calculation and analysis of $\mathrm{V}$-shaped groove parameters effect on the big debris mass, size, and verify the rationality of the case groove design. In Fig .1, "A" are big debris, "B" are small debris.

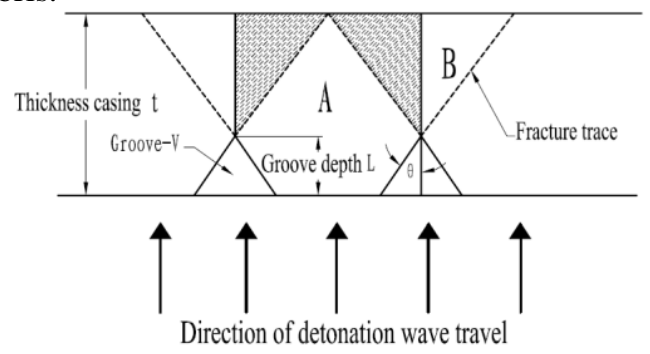

Figure 1. Model of the V-shaped groove

\section{DESIGN OF SHAPED CHARGE}

\section{A. Conventional case of shaped charge}

According to the requirements of construction of Bohai oilfield formation, shaped charge which suit for 7 'perforator as research object. The case material is 45 steel, theory of case weight is $481.6 \mathrm{~g}$, the charge is R852, the size of the inner diameter of $\mathrm{d}=48 \mathrm{~mm}$; diameter $\mathrm{D}=60 \mathrm{~mm}$; height $\mathrm{H}=66 \mathrm{~mm}$. Case design scheme is shown in Fig.2.
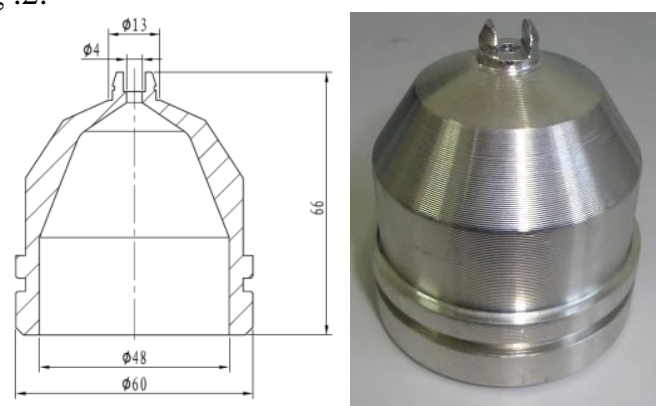

Figure 2. The conventional case profile and outline drawing

\section{B. Design of new shaped charge case}

The case material, charge type, charge charge and case dimensions are the same, the inner surface of case prefabricate weak structure. Along the case axial preformed several V-shaped groove[8-9], the theory of case weight $467.4 \mathrm{~g}$. The structure sketch is shown in Fig .3.
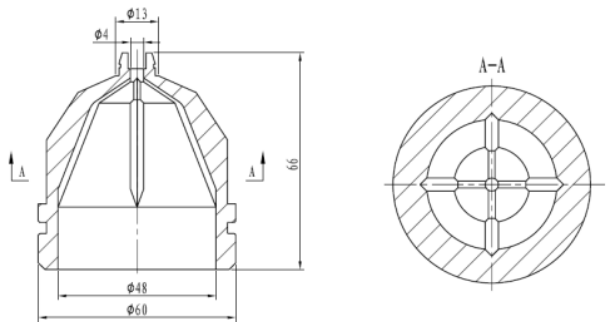

Figure 3. New design of case diagram and groove profile

\section{NUMERICAL SIMULATION ANALYSIS}

In order to prove the rationality of the structure, we calculate and analyze by using numerical simulation technology. Because of the axial symmetrical structure in shaped charge structure, we use 1/4 three-dimensional modeling method, use AUTODYN software modeling and grid division of explosive, liner, case, air, water, perforating gun, target, which are calculated in ANSYS/LS-DYNA. Because explosive, liner, air and water in the explosive detonation will produce large deformation and movement, we use ALE algorithm to calculate the above four kinds of materials; steel target, case, perforating gun calculate based on Lagrange algorithm. Unit algorithm use multi-material ALE algorithm, which simulate jet stretch, fracture and penetrating target. The finite element calculating model is shown in Fig .4.

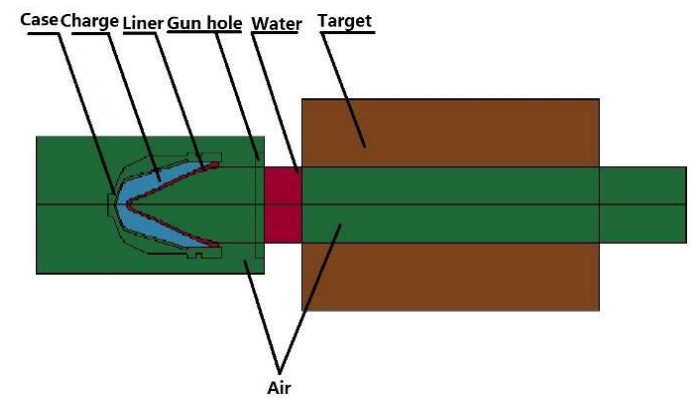

Figure 4. Sketch of finite element calculation model

\section{A. Results of numerical simulation and analysis of case fragment formation}

After explosion numerical calculation, the case of conventional shaped charge and new shaped charge debris formed effect comparison were shown in Fig .5.

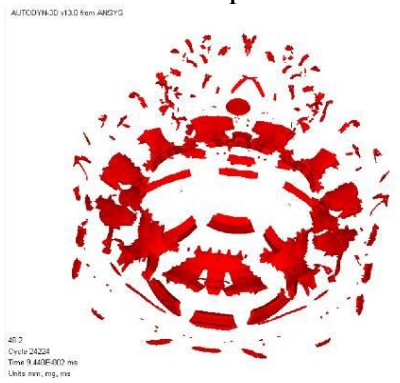

(a) Conventional case debris

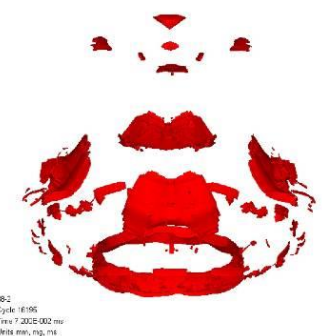

(b) New case debris
Figure 5. Effect of shaped charge case after explosion

From figure 6 , there is more small debris which is formed in conventional case break (a.).There are less debris in new case break, mainly formed into strip, lace, ring debris(b). The shaped charge which the structure of case carving $\mathrm{V}$-shaped groove formed large debris more easily.

\section{B. Results of numerical simulation and analysis of Jet Characteristic}

"Three section "liner which metal jet numerical simulation results shown in Fig .6. 


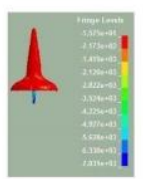

$T=12$ us
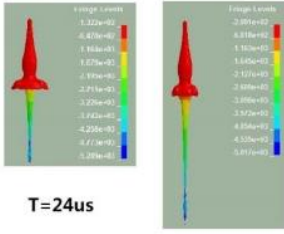

$\mathrm{T}=36$ us

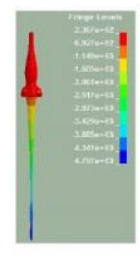

$\mathrm{T}=48$ us

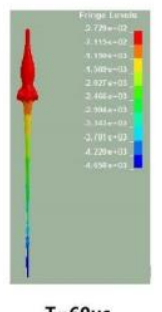

$\mathrm{T}=60 \mathrm{us}$
Figure 6. Jet effect chart of "Three section" liner

Numerical simulation of the target penetration results as shown in Fig.7.

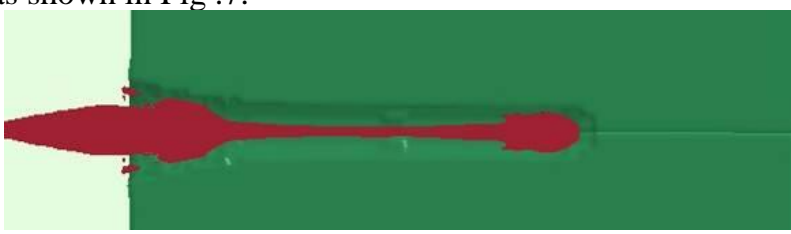

Figure 7. Penetrating the target effect chart

From Fig .7, after the formation of metal jet down jet head is fine, thick tail, thus forming a small hole in the perforating gun, the formation of large hole in the target. According to the numerical results, in the gun loaded standoff conditions, "Three section" liner diameter of perforation on casing can reach $21 \mathrm{~mm}$; penetration between $150 \mathrm{~mm}-160 \mathrm{~mm}$.

\section{FUNCTION TESTING STUDY AND RESULTING ANALYSIS}

Regarding to new design of perforating charges, we used stimulated loading gun steel target on surface testing, debris collection and comparing testing for signal shaped charge , and the testing way from 《debris collection process of shaped charge 》 from API 19B , and verify the safety and reliability of perforating equipment[10], and if the performance can meet the application requirement.

\section{A. Stimulated loading gun steel target testing on surface}

Used stimulated loading 7 " perforating gun and do steel target testing on surface, testing construction introduction chart and actual installation picture as following Fig .8.
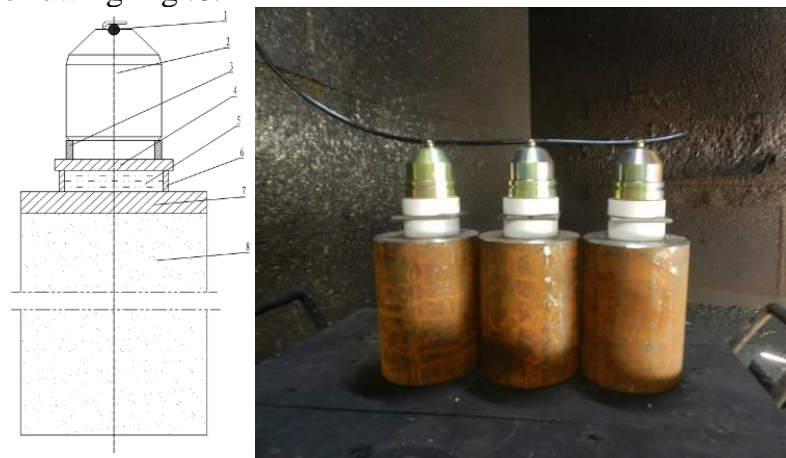

1-detonating cord; 2-shaped charge; 3-stimulated; 4-stimulated gun body; 5- clear water; 6-stand-off of casing; 7-stimulated casing; 8 - 45 steel target

Figure 8. The Introduction chart of Stimulated loading gun and steel target testing on ground and testing installation picture

\section{B. Debris collection testing of single shaped charge}

Used closed signal shaped charge debris collection testing way, and compared the debris condition of new design case and normal design case. As figure 10 showing, it is debris collection equipment and introduction chart. Collect the debris of single perforating charge, we did the same testing 3 times for two type cases. Ignore the weight of detonation from detonating cord, explosive and liners. The collected debris to do quantitative analysis with diameter of $9.53 \mathrm{~mm}(0.375 \mathrm{in})$ standard steel sieve. The paper mentioned $9.53 \mathrm{~mm}$ is casing diameter of perforating gun and it is produced by shaped charge is detonated and shaped jet-flow.
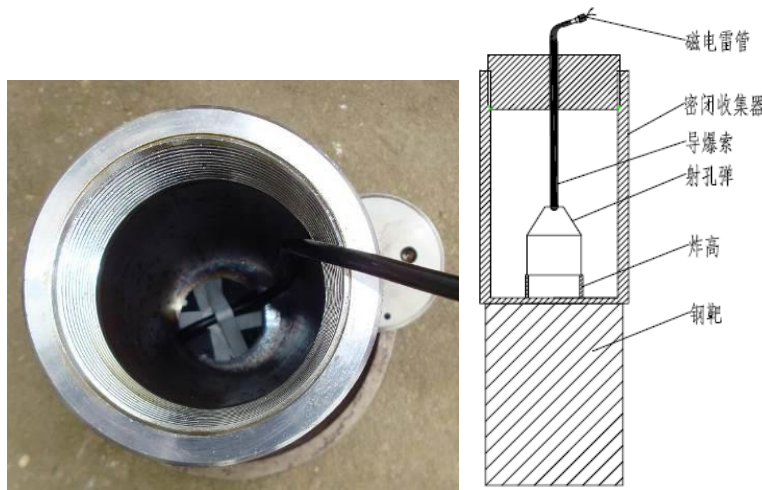

Figure 9. Debris Collection equipment and introduction chart

\section{Debris collection testing of perforators on surface}

We can't calculate the exact debris quantity in well bore as the complexity and volatility of well condition. So we use the testing way of 《debris collection process of shaped charges 》 from API RECOMMENNDED PRACTICE 19B and it is the 5th part and 2th version. As testing picture 11 showing, using the new design 7 " big debris perforating charges and installing the whole 7 " perforating gun, the raw material of gun body is $32 \mathrm{CrMo} 4$ from Baogang, and dimension is $\phi 177.8 \times 12.65$, the manufacturer of gun is CNOOC factory. Shot density is 40 hole/m.
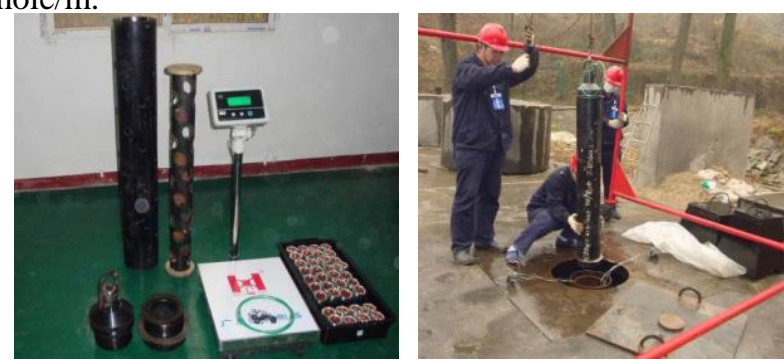

Figure 10. Testing equipment and testing site

\section{Resulting analysis}

1) The resulting analysis of Stimulated loading gun steel target testing on surface

To analyze the target body of Stimulated loading gun steel target of signal shaped charge, as Fig.11. 


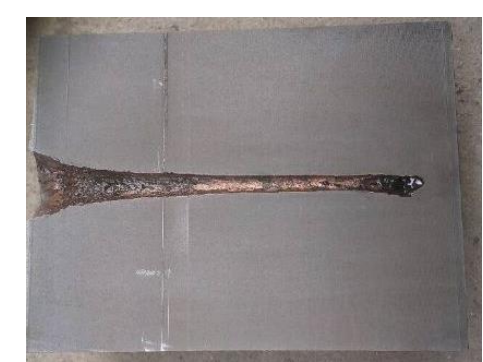

Figure 11. The Shape of jet-flow in steel target

From Fig .11, according to extension track of jet-flow in target steel, Compared picture8 stimulated steel target effect drawing, we can get that the actual jet flow is matching value stimulation.

2) The testing resulting analysis of signal shaped charge

According to debris collection of signal shaped charges, it is comparing picture of new design case and normal design case. The collection result as chart 1 showing.

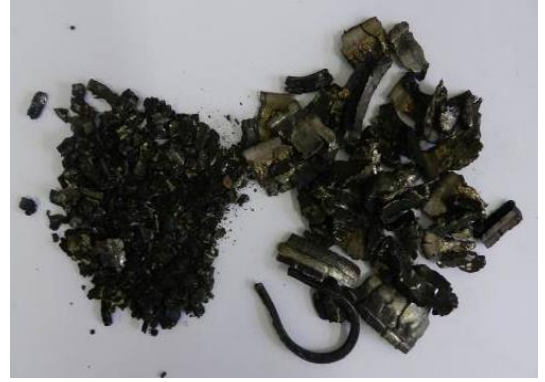

Figure 12. Debris of new design case

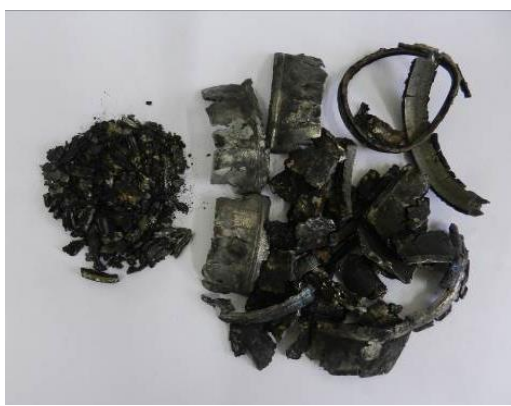

Figure 13. Debris of normal case

From Fig .12, We can understand that the shape from normal debris is not regular as detonation function, What's more, small debris is much, Fig .13 There is pre-control channel, debris is rectangle, and small debris is less, resulting is obvious .

TABLE I. THE DEBRIS COLLECTION CONDITION OF 7 " BIG DEBRIS SHAPED CHARGE SIMULATED LOADING GUN STEEL TARGET TESTING

\begin{tabular}{|c|c|c|c|c|c|}
\hline $\begin{array}{l}\text { Case } \\
\text { type }\end{array}$ & $\begin{array}{c}\text { average } \\
\text { weight }\end{array}$ & $\begin{array}{l}\text { weight of } \\
\text { collection }\end{array}$ & $\begin{array}{c}\geq 9.53 \mathrm{~mm} \\
\text { debris } \\
\text { weight }\end{array}$ & $\begin{array}{c}\leq 9.53 \mathrm{~mm} \\
\text { debris } \\
\text { weight }\end{array}$ & $\begin{array}{c}\text { Ration } \\
(\geq 9.53 \mathrm{~mm})\end{array}$ \\
\hline \multirow{3}{*}{$\begin{array}{l}\text { New } \\
\text { case }\end{array}$} & \multirow{3}{*}{467.4} & 457.4 & 398.4 & 58.8 & 85.3 \\
\hline & & 459.8 & 401.8 & 57.6 & 86.0 \\
\hline & & 448.6 & 403.9 & 44.6 & 86.4 \\
\hline \multicolumn{5}{|c|}{ The average value of big debris ration } & 85.95 \\
\hline \multirow{3}{*}{$\begin{array}{l}\text { Normal } \\
\text { case }\end{array}$} & \multirow{3}{*}{481.6} & 460.3 & 263.3 & 197.0 & 57.2 \\
\hline & & 459.7 & 291.9 & 167.8 & 63.5 \\
\hline & & 463.4 & 286.8 & 176.6 & 61.9 \\
\hline \multicolumn{5}{|c|}{ The average value of big debris ration } & 60.9 \\
\hline
\end{tabular}

From Table I, we can understand that new design case construction can increase the dimension of debris very obviously; The length of $9.53 \mathrm{~mm}$ debris is up to $85.95 \%$.

3) Collection debris of resulting analysis

The corresponding table of debris weight in different stage.

TABLE II. WEIGHT OF DEBRIS IN TESTING DIFFERENT STAGE

\begin{tabular}{|c|c|c|}
\hline Item & Testing contents & Weight \\
\hline 1 & $\begin{array}{l}\text { The GW of perforator(including explosive } \\
\text { articles) }\end{array}$ & $133.75 \mathrm{Kg}$ \\
\hline 2 & The NW of firing head before initiation & $129.6 \mathrm{Kg}$ \\
\hline 3 & The NW of firing head after initiation & $128.75 \mathrm{Kg}$ \\
\hline 4 & Losing weight after initiation & $0.85 \mathrm{Kg}$ \\
\hline 5 & $\begin{array}{l}\text { Lost weight and volume during } \\
\text { transportation }\end{array}$ & $798.5 \mathrm{~g} / 110 \mathrm{ml}$ \\
\hline 6 & $\begin{array}{l}\text { Lost weight for turning } 100 \text { circles of } \\
\text { perforators }\end{array}$ & $1.431 \mathrm{Kg}$ \\
\hline 7 & $\begin{array}{c}\text { The total weight of losing debris of } \\
\text { perforators }\end{array}$ & $2.22 \mathrm{Kg}$ \\
\hline 8 & Losing weight of debris for each feet & $1.079 \mathrm{Kg}$ \\
\hline
\end{tabular}

From c Table II, it is lost $0.85 \mathrm{Kg}$ for whole perforators after initiation, it shows the small part debris is dropped into wellbore along detonation; the losing weight of debris from inside gun body is $789.5 \mathrm{~g}$ during transportation. It is stimulated picking up perforating gun process, The perforator revolved $10 \mathrm{~min}$ and 100 circles after initiation , The total weight of collection debris is $1.431 \mathrm{Kg}$, So the weight of total collected debris is $2.22 \mathrm{Kg}$,For perforator , the losing weight of each feet is $1.079 \mathrm{Kg}$.

Classify for collected debris and calculate weight percentage, resulting showing as Table III.

TABLE III. CLASSIFY FOR COLLECTED DEBRIS AND CALCULATE WEIGHT PERCENTAGE

\begin{tabular}{|c|c|c|c|}
\hline Mesh segment $/ \mathrm{mm}$ & Weight/g & $\begin{array}{c}\text { Weight } \\
\text { percentage } / \%\end{array}$ & Remarks \\
\hline$S \geqslant 12.7$ & 0 & 0 & \multirow{6}{*}{$\begin{array}{c}9.45 \mathrm{~mm} ; \\
\text { The average } \\
\text { value of gun } \\
\text { body is } 9.45 \mathrm{~mm} \\
20.77 \mathrm{~mm} \\
\text { The average } \\
\text { value of casing } \\
\text { diameter is } \\
20.77\end{array}$} \\
\hline $12.7>S \geqslant 9.53$ & 17.0 & 0.76 & \\
\hline $9.53>S \geqslant 6.35$ & 492.0 & 22.07 & \\
\hline $6.35>S \geqslant 4.75$ & 200.5 & 9 & \\
\hline $4.75>S \geqslant 2.35$ & 588.0 & 26.38 & \\
\hline Through NO.8 & 931.0 & 41.77 & \\
\hline
\end{tabular}

According to testing date of Table III, the weight of debris dimension $\leqslant 9.53 \mathrm{~mm}$ is up to $99.24 \%$, it shows that most of debris is kept inside gun body after initiation; The dimension of dropped debris is smaller than hole of gun.

\section{APPLICATION ON SITE FOR BIG DEBRIS OF PERFORATOR}

In order to verify and check the safety and collection result of big debris perforator, and guarantee the safety and project quality, we did the testing in Bohai oilfield of CNOOC, The perforator on well site is $7 "$, and shot density is 40 hole/ $\mathrm{M}$.The perforating type is annulus pressure with time delay, the Table IV shows testing date on site 
TABLE IV.

DEBRIS COLLECTION DATE AFTER PERFORATING

\begin{tabular}{|c|c|c|c|c|c|}
\hline $\begin{array}{c}\text { Well } \\
\text { No }\end{array}$ & $\begin{array}{c}\text { Perforating } \\
\text { thickness/m }\end{array}$ & $\begin{array}{c}\text { Magnetic } \\
\text { bullet } \\
\text { fishing/Kg } \\
\text { space } \\
\text { between } \\
\text { packer } \\
\text { and } \\
\text { well- } \\
\text { end }\end{array}$ & $\begin{array}{c}\text { The losing } \\
\text { weight of } \\
\text { debris for } \\
\text { perforator } \\
\text { of each } \\
\text { feet }\end{array}$ & $\begin{array}{c}\text { The } \\
\text { falling } \\
\text { situation } \\
\text { of } \\
\text { packer }\end{array}$ \\
\hline $\begin{array}{c}\text { PL- } \\
\text { Xx }\end{array}$ & 56 & 86.1 & 3 & 0.47 & $\begin{array}{c}\text { Packer } \\
\text { in place }\end{array}$ \\
\hline $\begin{array}{c}\text { LD- } \\
\text { Xx }\end{array}$ & 93 & 132.4 & 5 & 0.43 & $\begin{array}{c}\text { Packer } \\
\text { in place }\end{array}$ \\
\hline $\begin{array}{c}\text { SZ- } \\
\text { Xx }\end{array}$ & 112 & 116 & 9 & 0.32 & $\begin{array}{c}\text { Packer } \\
\text { in place }\end{array}$ \\
\hline
\end{tabular}

From Table IV, from initiation of firing head to packing up perforator, the weight of losing debris for each foot is less than $0.5 \mathrm{Kg}$, the total weight of debris after perforating on surface is $1.079 \mathrm{Kg}$, and the actual debris weight is less than testing very much. The shaping of debris is good, and packer is in place, it has a small well pollution.

\section{CONCLUSIONS}

(1)As the object of study of case of big debris shaped charge with matching 7 " perforating gun, after numerical simulation. The shaping of new case is better than normal case, and the dimension of debris is increased much, and small debris quantity is becoming less.

(2)After steel target testing on surface, the OD of casing diameter is $21 \mathrm{~mm}$ on steel target, the wall of perforating hole is smooth and thick.

(3)Compared with debris collection testing of single shaped charges 'case, it is matching numerical simulation' result. The big debris ration of new case is higher than normal case very obviously.
(4)Used the new shaped charge to install the whole 7 " perforator , and did the debris collection testing, We can get that the small debris of outside gun body ,most big debris is kept inside perforating gun .

(5)After the testing in Bohai oilfield, this 7 " perforator can meet craftwork operation. The debris of weight of each foot is less than $0.5 \mathrm{Kg}$ after perforating, the actual debris weight is less than testing weight of $2.22 \mathrm{Kg}$, The shaping of big debris is good, and most debris is kept in gun body, it can guarantee the safety perforating operation and lasting well completion article smooth.

\section{REFERENCES}

[1] William Myers, Timothy Sampaon, Avigdor Hetz.Low "Debris Perforating Gun System For Oriented Perforating”. US,Jul. 3 ,2007.

[2] Jerry L,Walker,Fort Worth,TX. "Deberis reduction perforating apparatus and method for use of same". US.2006/0102352A1.

[3] Zhan L,Lafontan J L, Williams H,et al. "Method and apparatus for perforating with reduced debris in wellbore." US, 8424606B2.

[4] Myers W,Sampson T,Hetz “A.Low debris perforating gun system for oriented perforating."US, 20070119327.

[5] Ramos R, Leggett N. "Method and apparatus for logging a well using a firber optic line and sensors." US, 7900699B2.

[6] Xu Wenxin, Zhao Yuntao, Yao Zhizhong, ecld. "A shape charge of large debris and deep penetration.”CN,202850957,2013.

[7] Wang Feng ying,Liu Tian sheng. Damage "theory and technology". Beijing:Beijing.Institute of Technology Press, 2009, pp:97-116.

[8] Li Xiang dong,Qian Jian ping,Cao Bing,etal. Ammunition introduction. [M].Beijing: Defense Industry Press, 2004:261-262.

[9] Peng Zheng-wu, Zhang Qing, Wang Xiao-ming et al. The Effect of Groove Parameters on the Formation of Preformed Fragments. INITIATORS\&PYROTECHNICS, vol.1,2013, pp:17-20..

[10] American Petroleum Institute.Recommended practices for evaluation of well perforators $[S]$.2nd edition.2006. 